\title{
MACEDONIA: INTERNAL SECURITY CHALLENGES - A MISMATCH IN THE MACEDONIAN DEFENCE INSTITUTIONS
}

\section{МАКЕДОНИЈА: ВНАТРЕШНО БЕЗБЕДНОСНИ ПРЕДИЗВИЦИ - НЕСОВПАЃАЊЕ ВО МАКЕДОНСКИТЕ ОДБРАНБЕНИ ИНСТИТУЦИИ}

\author{
Sasho Kuzmanovski, MA \\ Ministry of Defense, Republic of Macedonia \\ E-mail: saso.kuzmanovski@morm.gov.mk
}

\begin{abstract}
It is no longer a question whether we need a defense reform, but rather, who can do it? The Macedonian Government for years has been practicing a so-called functional separation of executive positions among political coalitional partners in the Ministry of Defense and "political intervention" in the army, which brought a period of low cohabitation, and thus dysfunction and low efficiency. The current structure of the defense system in itself is a challenge, if not a risk and threat. Functional degradation of the defense system, i.e. the continuous loss of functional logic and justification, is evident. Therefore, it may be pointless in the new social conditions to repeat repeatedly Buzan's Defense - Security Dilemma or to compare which security threats - external or internal - are more important and influential for a sustainable defense - security system.
\end{abstract}

Throughout this context, it seems that the institutional integrity, regardless of the nature of modern challenges and the development of the global civil society, social movements, and media, is one of the key foundations, conditions, and prospects of the defense - security organization.

Hence, it is necessary to question the integrity of the defense institutions, especially the one of the Ministry of Defence (MOD) as a leading institution among them, and whether they can fulfill the needed level of the tasks set in front of them, how they perform the prescribed powers and functions, which factors affect the credibility of the institutions, who shapes the defense policy, and is there a necessity for a defense system.

The participants in the defence system, the MOD employees, as well as the political parties and citizens each in their own way influence the internal defense - security challenges. However, through systemic institutional analysis and methodology of assessment of the segments of func 


\section{Seccurity}

tional efficiency of the institutions, we will get results that point out a general perception of depreciation and mismatch (discrepancy) in the defense system. The logical conclusion of the derived results would be "ineffective institutions equal dysfunctional defense." As an implication of the survey, this would mean a necessity of a systematic reorganization and a change in the social relations and the relations of the authorities responsible for and about the defense.

Will a critical mass be created in the near future, remains an open question. However, one thing is certain: at best, someone will have to address the issue about what is actually happening in the field of defense in front of the taxpayers; or at worst, someone will have to answer the question when it will become a source of new crisis and the basis for a new internal conflict.

The reality is, after more than 20 years of independence we should again ask ourselves whether and what kind of defense institutions we need, so that they alone do not create an internal security challenge for the country.

Keywords: integrity, credibility, defense institutions, internal challenges.

АБСТРАКТ: Веќе не е прашање дали се потребни реформи во одбраната, туку кој тоа може да го направи. Владата години наназад практикуваше нефункционална поделба на извршните места во М0 и „политички интервенции“ во армијата, што донесе период на ниска кохабитација, а со самото тоа и дисфункционалност и ниска ефикасност. Сегашната поставеност на системот за одбрана сама по себе е предизвик ако не и ризик и закана. Функционалната деградација на системот за одбрана, односно континуираното губење на функционалната логичност и оправданост е евидентна. Затоа, можеби е беспредметно во новите општествени прилики да се повторува повторно и повторно одбранбено - безбедносната дилема на Бузан, или е несоодветно да се споредува кое, надворешното или внатрешното безбедносно загрозување е позначајно и повлијателно за одржлив одбранбено - безбедносен систем.

Во целиот тој контекст се чини институционалниот интегритет, без оглед на природата на современите предизвици и развојот на граѓанското глобално општество и социјалните медиуми и движења претставува една од клучните основи, предуслови и перспективи на одбранбено

- безбедносното организирање. Оттука неминовно е да се запрашаме за интегритетот на одбранбените институции, посебно Министерството за одбрана (М0) како водечка институција меѓу нив, дали истите се на висина на задачите поставени пред нив, како ги извршуваат пропишаните надлежности и функции, кои фактори влијаат на кредибилитетот на институциите, кој ја креира одбранбената политика и дали воопшто постои потреба од одбранбен систем.

Учесниците во одбраната, вработените во М0, политичките субјекти и граѓаните влијаат секој на свој начин врз внатрешните одбранбено - безбедносни предизвици. 


\section{Secururity}

Меѓутоа, преку системска институционална анализа и методологија на проценка на сегментите на функционалната ефикасност на институциите ќе дојдеме до резултати кои оставаат општа перцепција на депрецијација и обезначување на одбраната. Притоа логичка фраза на заклучок од изведените резултати би била: „неефикасни институции се еднакви на нефункционална одбрана“. Ова од своја страна како импликација од спроведеното истражување би значело нужност од системска реорганизација и промена на односите во општеството и односите на надлежните авторитети за и кон одбраната.

Дали за тоа во блиска иднина би се создала критична маса останува отворено прашање. Но едно е сигурно, во најдобар случај некој ке мора да одговори на прашањето час поскоро пред даночните обврзници што навистина се случува во доменот на одбраната или во најлош случај некој ќе мора да одговори на прашањето откако тоа ќе стане извор на нова криза и основа за нов внатрешен конфликт. Едно е неопходно реално, дека и после повеќе од 20 години самостојност треба да се запрашаме повторно какви и дали воопшто ни се потребни одбранбени институции за да тие сами по себе не претставуваат внатрешен безбедносен предизвик за државата.

Клучни зборови: интегритет, кредибилитет, одбранбени институции, внатрешни предизвици.

\section{Instead of introduction}

In the past 20 years, the defense had its good and bad years with peaks and troughs in their development and transformation. In certain periods 1997-98 and 2003-05 was a leading institution and an example for a swift and efficient transformation in Southeast and Central Europe. In that period a first strategic defense, documents were established 33 and their implementation was started. In parallel functions and consistency of the values in defense or professional ethics were settled, opportunities and threats anticipation were calculating, also an analysis and interpretation of developments in the future and the capacity to act. Simply the basics of defensive integrity were realized. In other words, this meant institutionalization of practices, relationships, norms and manners in defense.

However, as time passed, implementation and lifecycle tracking changes or checking and balancing the actual effectiveness appears to have become our genetic developmental problem.

33 "First Defense Strategy and the Defense White Paper were adopted in 1998, Concept of Defense in 2003 and Strategic Defense Review 2004. 


\section{Seccurity}

Due to growing complexity, it became more difficult to anticipate, analyze and interpret the future and the threats it brings. Despite that it seems we faced period of prolonged lethargy in defense and erosion of a just established defensive integrity.

Actually, the defense as any other social category is impartial and at permanent exposure to new permanent incremental change (threats) that need to find an answer with the same or less money, or how scholars say, "to do more - with less."

To find her-self (defense) selected as a priority among other social functions it is not necessarily to wage war, but to understand and redefine functional structure according to available resources and capacities, meliorating the both, modern challenges and traditional prejudices. To be successful, it is generally accepted that defense needs indispensable and permanent analysis of the situation, institutional commitment and professionalism ${ }^{34}$ and unbreakable relationship with the institutional integrity and good governance, which essentially are indicators for the overall development of the country.

However, the reality is bitterly different. Today, the defense functions are reduced, or at least the same as 10 years ago, capacities and capabilities, if subjected to realistic, independent analysis, I believe are even modest, and it seems one could recognizes dysfunction from afar, which is reflected in the fact that as the largest internal threat, probably greater than any external contemporary threats, is the lack of institutional capacity although it is estimated that defense is primarily aimed at defending the sovereignty and integrity of the state from an external enemy.

But where does this conclusion. Perhaps you should first compare the situation, to look at the legislation and ways of governing the matter, then in terms of actual implementation and functionality, and in the end in ethics and institutional integrity.

\section{Background and analysis of the situation}

Within the first legal solutions, strategic documents and bylaws but also with the initial enthusiasm and commitment the foundations of the functionality and institutional integrity were established. Significant support for building principles in the defense came from NATO and the international community. Republic of Macedonia (RM) in building principles of defensive action progressed extremely well. After all RM didn't have a need of the Partnership Action Plan on Defense Institution Building (PAP-DIB) which in 2004 was introduced by NATO for defense democratization of

\footnotetext{
34 Guide to Governance 01/15, Professionalism and integrity in the public service: A matter of good governance, 2015, Centre for Integrity in the Defense Sector, p.4.
} 


\section{Seccurity}

Eastern European countries in transition. Macedonia was capable to solve its challenges alone. Under Article 1 and 2 of the PAP-DIB, "Member States of the Euro-Atlantic Partnership Council (EAPC), reaffirm their conviction that effective and efficient state defense institutions under civilian and democratic control are fundamental to stability in the Euro-Atlantic area and essential for international security cooperation. They agree to establish a Partnership Action Plan to support and sustain further development of such institutions across the Euro-Atlantic area "35

"Partnership Action Plan on Defense Institution Building aims to strengthen the efforts of the EAPC partners to initiate and continue the reform and restructuring of defense institutions to meet their needs and the commitments undertaken in the context of the Framework Document Partnership for Peace and EAPC basic document and the relevant OSCE documents including the code of conduct of the OSCE politico-military aspects of security." ${ }^{\text {"36 }}$

According to PAP-DIB, the development of effective and democratically accountable defense institutions among other means stipulate: for the democratic control of defense activities, including appropriate legislation and coordination arrangements for determining the legal and operational role and responsibilities of key state institutions, procedures to promote civilian participation in developing defense and security policy.

However, multiyear lethargy in defense and its treatment of less significant institutional branch in Government, have led to drastic changes and loss of vision for building integrity in defense. Consequently, NATO in 2012 introduces a new partnership goal entitled "Building integrity"(BI), which since 2014 has been recommended to Macedonia and in a way, represent a tool for action in those countries that have a low degree of $\mathrm{BI}$ in defense to make an effort to advance. Hence, this can only be interpreted as a reality of the situation with $\mathrm{Bl}$ in defense in Macedonia and left us to wonder whether in present time the derived content that PAP-DIB provides has been accomplished.

Intrastate, defense and Ministry of Defense (MOD), as its institutional representative, although has its own inherent specifics, by its nature falls under the group of administrative civil service or simple, public administration. It shall be lead by established functional criteria and includes several administrative principles of governance which just because of Euro-Atlantic integration aspirations, has historically been harmonized with European ones.

35 http://www.nato.int/cps/en/natohq/official_texts_21014.htm?

36 Ibid. 


\section{Seccurity}

The main domains of administration that are complementary criteria for good governance of the defense sector are analyzed in the OSCE report for the Western Balkans. ${ }^{37}$ According to the report, the domains of administration management include: the adoption and implementation of reform programs of the administration, establishment of institutions for administration management at the central level, the establishment of a real system of values of employment, the establishment of mandatory rules of the state administration that stabilize public administration and protect employment, development of professional and depoliticized civil service system, the establishment of a fair and effective system for performance management (performance) of civil servants, the establishment of a predictable and transparent wage system, the establishment of a system that provides a regular and effective training and development of civil servants, establish a management system integrity which provides guidelines for ethical behavior in public administration.

In 2010, Macedonia has adopted Program for Administrative Reform, which is partly in line with European principles of administration. The first laws on administration, has been adopted in 2000, while last amendments were approved earlier this year. According to the report although generally acceptable, laws relating to public administration as usual "suffer from ambiguous and / or inadequate definitions that undermine their capacity to ensure the principles of legal predictability and accountability of public administration." 38 Recent developments indicate growing pressure on narrowing the scope of laws on state administration from the top down, especially in the direction to facilitate political appointments to managerial positions in public administration. The report also recommends stronger oversight of amendments to the laws and regulations relating to public administration to prevent the tendency of acting outside the legal framework.

The report stresses and absolute truth, which is that "despite the relatively good formally legal solutions, it is important to recognize that the adoption of the laws on public administration, which include defense, is not sufficient to professionalize it. Also adoptions of the reform programs, as well as the adoption of laws do not go far beyond the stage of declarative and symbolic politics." 39 If its try, whether this is also an absolute truth for administration officials working in the Ministry of Defense.

\footnotetext{
${ }^{37}$ Meyer-Sahling, J. (2012), "Civil Service Professionalisation in the Western Balkans", SIGMA Papers, No. 48, OECD Publishing. 38 Ibid.

39 Ibid.
} 


\section{Secururity}

Hence, the establishment of a real system of values (merit) in recruitment for employment, which includes an open competition for entry (based on equal conditions), applying expert exam and provision of independence from political influence in defense despite declaring efforts has a weak implementation in the practice and employment has been characterized with the high degree of informality and favoritism, use and abuse of discretion, and a high degree of protectionism.

Social, political and economic context fails to provide for conditions for the professionalization that neither is present in any employment practices nor it is part of the internal selection system for education and training. It is also the general practice with the selection for mission deployment, promotion, rewarding or providing involvement in projects with financial gains where selection is not under the adequate competencies. On the other hand, Ministry's strategic priorities reputedly are "improving the efficiency and effectiveness of the MOD, and Army of the Republic of Macedonia (ARM) modernization and transformation". If this is a real priority, it is realistic to expect that after so many years, the MOD will produce real progress and finally achieve projected goals. However, for the time being it seems, it will remain the same.

Furthermore, it is true that the protection of public employment should serve to promote the principles of political neutrality and impartiality of public administration, but currently there are no indications that would confirm that these principles are truly present not only in the reform of public administration programs but also in practice.

Pursuant to the exercise of the fundamental domains, the results of the OSCE survey on public administration of the Western Balkan countries are showing "a mixed picture of achievements where weaknesses continue to exist. The main weakness of the system of public administration is the low level of effective governance combined with a low level of sustainability of reforms." ${ }^{140}$

Although it doesn't distinguish her from the rest in negative sense, what should concern the RM is the fact that the prospects for achieving sustainable professionalization of public administration, especially in the field of defense are low. While there has been significant progress in the area of formal legal institutionalization, there is poor quality implementation.

RM trajectory of the reform of public administration in terms of domestic conditions is largely unfavorable for the professionalization while international context can affect the sustainability of reforms, if it stays actively involved.

40 Ibid. 


\section{Seccurity}

If that is the case, a question whether reforms are needed in the defense is no longer current but who can those managed and how can implement foreign experience. For years functional separation of executive positions in MOD and "political intervention" in the army has been practicing, which brought a period of low cohabitation and thereby the dysfunction and low efficiency. The current structure of the defense system in itself is a challenge if not a risk and threat. The continuing loss of functional logic and justification is more than evident.

Therefore, it may be pointless in the new social circumstances to repeat repeatedly Buzan's defense - security dilemma, ${ }^{41}$ or to compare which security threats, external or internal are more important and influential for a sustainable defense - security system.

Just when we talk about the functionality, it should be known that the MOD is the first institution in the Republic, which had prepared a functional analysis 2004-05 that complement the Strategic Defense Review (SOP), and comply with the following transformation. The last three to four years, although it was prescribed the MOD recognized the need for a new functional analysis, but as there was inability to such a document to be adopted. According to the legislation on public administration all institutions have a responsibility for producing functional analysis as a condition and requirement for the adoption of new organizational documents so it remains to believe that they managed to draw up a document that at least in a case of the MOD has not been published yet. In the overall context it seems that institutional integrity, regardless the nature of modern challenges and the development of global civil society and social movements and media, is one of the key fundamentals, conditions and perspectives of organizing defense and security.

Hence, it is necessary permanently to pose a question about the integrity of defense institutions, especially in the MOD as a leading institution among them, whether they are up to the tasks accomplishments, whether and how they pursue the prescribed power and functions, which factors affect the credibility of the institutions, and who is shaping defense policy and how.

Participants in defense, the MODs' staff, political parties and citizens, influence on their own way on the internal defense - security challenges. Despite that, it seems that some of them are in certain inertia. Pursuant to opinion polls regarding the "trust in people and institutions ${ }^{42 .}$." the ARM which is traditionally perceived as much more respective institution then MOD itself, retains the same high level of relevance.

\footnotetext{
${ }^{41}$ Barry Buzan, People, States and Fear, Wheatsheaf Books Ltd, London, 1983, p.207-209

42 The survey was conducted in 2013 by the Macedonian Center for International Cooperation.
} 


\section{Seccurity}

However, according to the results, in fact, it has seen its fall from first place in trust in 2012 to fourth in 2013, given that confidence in other institutions such as educational institutions, health care organizations, and the police has grown significantly.

This course has been partially corrected in the coming years, but it is only a confirmation of variability in the defense segments. Still, a public opinion poll conducted by the Centre for research and implementation of policies - Skopje in 2014, again confirms that armies are the most trusted in the region. In Macedonia, more than $71.5 \%$ of respondents gave their support to the ARM. ${ }^{43}$

Citizens Association "Most" in 2013 also presented the results of the regional project "Using new media in promoting the transparency of governments" 44 , according to which transparency in relation to the defense, MO shares seventh place with four institutions. In this context in relation to employment data, only the Ministry of Information Society and Administration has a link to the Administration Agency on its website. In terms of budget transparency and free access to information, MOD has not released information on the budget for 2013 nor has published information on requests for access to public information. The results with respect to the other areas and indicators are also negative.

If the relationship, given the above presented research results point to say that the state of defense in terms of functionality and internal relations and challenges, is "symptomatic" then what the status in relation of modern threats is. Are there capacity competent authorities to assess which combination of modern threats can be the most vulnerable for RM and whether it will be timely assessed or after being reported?

In this context, RM fits uneasy. Judging according to public information, the provisions of strategic documents, statements by former Ministers of Defense of the Republic of Macedonia, modern challenges are similar to those within the region, European and even global one with one specifics that economic conditions, unemployment, and poverty continues to be perceived as the biggest challenges, and have more of relevance then i.e. current crisis with the immigrants which has not being perceived as immediate and real threat that could explode into a new regional disaster.

The latest Euro-barometer survey, whose results were published on 31.07.2015, says that "while immigration is the biggest problem for Europeans, greater than the economic crisis and unemployment, for the people of Macedonia biggest problem is unemployment and the economic situation and the rise in retail prices."

\footnotetext{
${ }^{43}$ The survey results were published in Macedonian media 09.03.2015

${ }^{44}$ Full survey results can be found on the website http://otvorenevlade.cdtmn.org
} 


\section{Secururity}

Results also show that Macedonian citizens have much greater confidence in European institutions than in Macedonian one. This perception of internal problems and external challenges, questioned whether the institutions could accurately identify priorities in a slew of global and national challenges.

At the end it seems that systemic institutional analysis by assessing the segments of the functional efficiency of MOD as an institutional defense representative will come to real observations to confirm or reject the general perception of depreciation and depleted credibility. Nevertheless, we should try to asses this statement through the 0 check through the parameters of principal defense representatives.

\section{Basic parameters of the principal defense representatives}

The basic parameters of the principal defense representatives (MOD, General Staff (GS) of the ARM and ARM itself) can be evaluated according to financial, transformation, personal, legislative, and if you want functional solutions.

Financial solutions are actually a reflection of the engagement of the budget where over $65 \%$ relate to personal costs. The percentage of GDP allocated for defense in 2005 despite the policy projected 2.3 to $2.6 \%$ ends up with realistic $2.16 \%$. Ten years later it was reduced by almost $50 \%$ at the current level of $1.16 \%$. Within such financial preconditions, defense had to drastically reduce or functionally reorganize. Since 2005, with the formation of the Crisis Management Center, the Protection and Rescue Directorate and the Border Police, the Ministry of Defense has being released of the general obligations for crisis management and protection and rescue on the state level as well as permanent commitments to guard the border line. The same year the Military Academy was abolished and in 2006 the Military Hospital with its larger part were transferred to the public health sector and the Army become fully professional which left MOD to take care only for administration of the military service candidates and voluntary service in the ARM.

Many functions have declined, and after receiving a "delayed" invitation for NATO membership in 2008 we have not increased other functions in terms of capacity building for collective defense and security. In 2005 the overall functions performed fewer than 600 employees with twice bigger budget, and today it is speculated that the new organizational document subsume double number of personal while budget is tight twice. Those circumstances are unavoidable and they cannot lead to a conclusion on quality. Army figure is less built but increased ranks further twist the pyramid and now we have more senior ranks of the needs and those projected with the SDR. To alleviate this situation the Military Academy was restarted which produces extra young officers, and it seems it has been done at the expense of soldiers and combat units that have less and less personnel so the 


\section{Securiarity}

extension of the contracts of professional soldiers up to 45 years was eminent that from the other side invalidated functioning of the "Lepeza project", intended for the resettlement of soldiers, NCOs and officers personnel.

In the officer corps has elders 10 years eligible for promotion but "by certain circumstances" are not enlisted for higher rank, while others deployed in MOD take the place of public administration civilian colleague. The very same public administration civil servant fully accomplish same duties having a lowest admin rank of junior associates while with interventionist change in the organizational structure the officer obtain a higher rank doing the very same job from lieutenant up to colonel retaining the same job position. Takeovers, new hires or promotions with possible rare exceptions can easily fall under the perception of favoritism, nepotism, patronage, and clientele interventionism.

But it is not our seemingly pressing issue. The Ministry has another interesting phenomenon. It seems distinctiveness of public servants - defense specialists, much easily blurred into "general" administrative civil servants within the public administration. Anyone can operate in defense and in parallel to be an expert on agriculture, and perhaps advisor for education and health etc, etc, but the real defense experts are lost in the generalization of public administration.

But the MOD has other peculiarities too. More than 50\% of leading positions of managers or service duty in MOD, a category that the new Law on administration incidentally does not recognize, are filled by military personnel. It undermines civil-democratic control. Curiosity is that there is also concentration of four to five executive positions covered by one person. Although it is legitimate in terms of conducting functions while certain places are vacant, it should not be forgotten that sharing information and responsibilities should ensure avoidance of absolute control over the decisions, while the concentration of power, can be a major risk factor of corruption. For having, a full picture there is a MOD web portal that post information about opportunities for courses, education, training, and selection of candidates. Drawbacks may be that there is a candidate selection sometimes that is selected for two activities which are executed but it is probably due to a technical error.

In addition, despite all the amendments to the basic legislation to the Defense Law, Military Service Law and Low on public administration, systemic inequality between civilian and military personnel in the MOD has been created. One example is long and complex procedure for selection and placement of civilian professionals with years of experience in managerial positions at the expense of the simple procedure of changing the systematization document and exchange between the envisaged administrative officers with an alternative setting for military personnel that does not apply complex procedure. 


\section{Seccurity}

Another example of inequality is the verification and cash compensation for acquired higher educational title for the officers to be applied automatically, but for civilians to be limited by the need for prescribe a specific position for MA or PhD holder, which with ultimate exceptions almost never happens, no matter whether the person who acquired the title of higher degree was sent for education by the MOD or s/he privately promoted his educational degree.

In GS as an integral part of the MOD and ARM in general, the method of rotational placement as in all armies of three to five years especially for the key positions is well known. However, there are examples after 10 years that, certain positions are still filled by the same officers. Also certain media sometimes expressed objections to the manner of selection of candidates for referral missions and others argue that the mandate of the Army Chief has already expired almost one year before, which is not so terrible if its understand as well-intentioned public control of the situation in defense. It might feel concerned that defense institutions have lost its power in terms of military issues and establishing procedure for selection of candidates for military/ defense representatives abroad according to official responsibilities and bylaws are avoided.

Finally according to the situation in both integral parts (MOD and GS), it is difficult to assume that there is a place for civil-democratic control of defense.

Hence, the MOD and ARM its necessary to reread the Criteria for good governance in the defense sector ${ }^{45}$, where corruption in a wider sense, is the ineffectiveness of the institutions, system failure or hole. According to the criteria, "corruption or unethical behavior is also defined as" institutional practices that compromise the institutional capacity to perform its functions in an unlimited and accountable way." ${ }^{46}$ Someone here might notice why forcing the category of corruption in this context. According to the survey conducted by the State Commission against Corruption and the Rating Agency in 2013, citizens perceived political parties as the most corrupt, followed by ministries and Government and the President and Parliament. According to the information presented, MO is not excluded from the group of ministries. And if this is just a wrong perception, it should be the basis for further analysis and exploration of the ways to overcome this situation.

\section{Conclusion}

Ineffective institutions are equivalent to dysfunctional defense. This implies the necessity of a systemic reorganization and changing relationships in society and relations between the competent authorities and to the defense.

\footnotetext{
${ }^{45}$ Criteria for good governance in the defense sector: International standards and principles, Centre for Integrity in the Defense Sector, 2015.

46 Ibid
} 


\section{Securiatity}

Is it possible that a critical mass would be created in the near future, remains an open question? But one thing is certain, at best someone will have to answer the question as soon as taxpayers ask for, what is really happening in the domain of defense, or at worst someone will have to answer the question as it would become the source of a new crisis and a basis for new internal conflict.

Finally, on the question whether reforms are needed in the defense for its greater efficiency, the answer is undoubtedly positive with the emphasis that we should be familiar with the ways in which we want to develop defense, be determined on the basis of comprehensive analysis that will lead us to a future functionally positioned defense. It should understand also a revision of normative acts and their congruent normative harmonization. The existing legal documents are one of the sources of inefficiency, confrontation and resentment. If they undergo the constitutionality and legality before an independent judicial authorities in several dozen cases would show unconstitutionality and illegality, which can be confirmed through the large number of dispute cases conducted before the competent courts. Equally dysfunctional are strategic documents with a multilingual white papers on defense too, which are just a copy of old documents phrases without substantial reflection of the real modernity.

In terms of funding and defense costs, we can say that the principle of stable defense funding, which was based on realistic projections, has long been abandoned. Furthermore if you increase defense institutions staff by 100 to $150 \%$ of the projected SDR, while you have less functions and aging of the officer corps like in Belgium and Portugal, then chronic hollow Army units and responsibility for the admission of professional soldiers that their contract has ended, even if you allocate $4 \%$ of GDP on defense, those funds will not be sufficient.

The current structure of the defense system in itself is a challenge if not a risk and threat. The continuing loss of functional logic and justification is evident. The limited use of military assistance to civilian authorities, talks to reduce the functions or if you want basic goals and objectives. Its use outside the RM within the operation to maintain peace, as operations to achieve real benefit for RM on economic - political or value - driven motives, have a potentially controversial justification.

Hence, when we talk about reorganization and probably we will again come to the need of BI.

For the $\mathrm{Bl}$ and ethical leadership as commonly defined, is important not only to focus on the code of conduct, the application of the mechanisms of individual competencies but also the interaction of individual integrity (individual behavior), the institutionalization of norms of integrity (in context operated) and the integrity of the institution (the relationship between the institution, leaders and individuals). ${ }^{47}$

47 Eduard Grebe and Minka Woerman, Institutions of integrity and the integrity of institutions: Integrity and ethics in the politics of developmental leadership, Developmental Leadership Program, Research Paper 15, 2011. 


\section{Seccurity}

To achieve this, redefinition of relations is necessary primarily at the state level, something that will involve drastic reduction of the protectionism that affect public administration in defense and an independent expertise on the conditions and directions of action.

Otherwise, the only reality and necessity, which remains current, after more than 20 years of independence, is again to ask what defense institutions we need, so they do not represent an internal security challenge for the country.

\section{REFERENCES}

1. First Defense Strategy and the Defense White Paper, 1998, Concept of Defense in 2003 and Strategic Defense Review 2004.

2. Guide to Governance 01/15, Professionalism and integrity in the public service: A matter of good governance, 2015, Centre for Integrity in the Defense Sector.

3. http://www.nato.int/cps/en/natohq/official_texts_21014.htm?

4. Meyer-Sahling, J. (2012), "Civil Service Professionalisation in the Western Balkans", SIGMA Papers, No. 48, OECD Publishing.

5. Barry Buzan, People, States and Fear, Wheatsheaf Books Ltd, London, 1983, p.207-209\

6. Survey conducted in 2013 by the Macedonian Center for International Cooperation.

7. http://otvorenevlade.cdtmn.org

8. Criteria for good governance in the defense sector: International standards and principles, Centre for Integrity in the Defense Sector, 2015.

9. Eduard Grebe and Minka Woerman, Institutions of integrity and the integrity of institutions: Integrity and ethics in the politics of developmental leadership, Developmental Leadership Program, Research Paper 15, 2011. 